\title{
The Legacy of a "Cell Whisperer": Celebrating the Life of Dr. Prabodh Kumar Gupta
}

Dr. Prabodh Kumar Gupta (March 1, 1937, to December 23, 2020), who many of us had the privilege to know as a teacher, mentor, and a friend, was known for his bold presence and love for cytopathology. In his book entitled My India My America: Success Yatra, he wrote that "I had many adventures and a very exciting childhood. In the lottery of life, I had the lucky ticket: a supporting family and friends and good karma." Dr. Gupta was born in the town of Shorkot in the state of Punjab in undivided India. Dr. Gupta received his medical degree and pathology training at the All India Institute of Medical Science in New Delhi. He completed his training and clinical fellowship at the Massachusetts General Hospital in Boston and the Johns Hopkins Hospital in Baltimore. Subsequently, he returned to India and established a cytopathology laboratory in New Delhi. He then joined the faculty at Johns Hopkins, working with Drs. John Frost and Yener Erozan. In 1988, Dr. Gupta transferred to the University of Pennsylvania, where he continued his illustrious academic career until his retirement after 25 years of dedicated service as Professor of Pathology and Laboratory Medicine and Director of Cytopathology at the University of Pennsylvania Health System.

One of Dr. Gupta's most remarkable qualities was his tireless enthusiasm for teaching. As he remarked in his retirement speech, a passion for teaching is in his DNA! Throughout his career, he used every available tool, format, and venue to teach medical professionals, including cytotechnology and medical students, pathology residents, cytology fellows, and practicing cytotechnologists, pathologists, and clinicians, as he conducted daily conferences in his cytology laboratory and delivered over 200

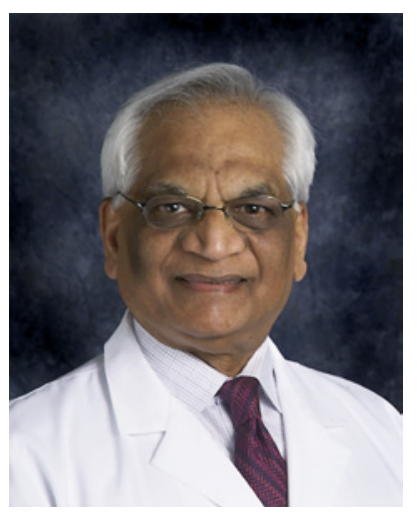

Dr. Prabodh Kumar Gupta (March 1, 1937, to December 23, 2020)

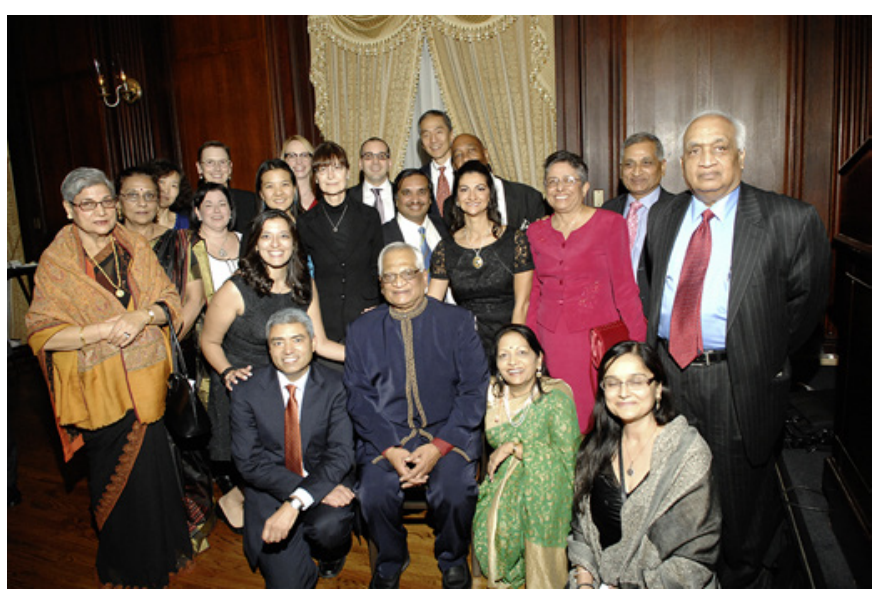

Dr. Gupta with his family and friends at his retirement party.

This obituary appears as joint publication in Diagnostic Cytopathology and Journal of the American Society of Cytopathology. karger@karger.com

www.karger.com/acy

Karger ${ }^{\prime}=$
Zubair W. Baloch

Department of Pathology and Laboratory Medicine

University of Pennsylvania Medical Center

3400 Spruce Street, 6 Founders Pavilion, Philadelphia, PA 19104 (USA)

baloch@pennmedicine.upenn.edu 
lectures, workshops, and seminars at local, national, and international meetings. He served on the International Academy of Cytology Committee for Examinations for the past two decades. Many of his trainees now hold leading academic positions throughout the USA. In acknowledgement of his great contributions to cytology education, Dr. Gupta received the 2011 "Excellence in Education Award" of the American Society of Cytopathology and the 2012 "L.C. Tao Educator of the Year Award" of the Papanicolaou Society of Cytopathology. A testament to his clinical expertise is being named among the top $1 \%$ pathologists in the country by US News and World Report, America's Top Physician numerous times, and was named a "Super Doctor" in Philadelphia in 2013.

Dr. Gupta spearheaded and collaborated in numerous research projects on various aspects of cytopathology, including important studies on the problems associated with the use of intrauterine contraceptive devices and early lung cancer detection. He published over 270 scientific papers, editorials, books, and book chapters, and served on editorial boards of several medical journals and contributed to the scientific and educational missions of a number of national and international organizations, including the National Science Foundation, the National Institutes of Health, Centers for Disease Control, and the World Health Organization.

As a member of the American Society of Cytopathology (ASC) for almost five decades, he served on numerous committees and chaired several, including the Budget and Finance, Awards, Editorial and Publications, and
Nominating Committees. He served as a member of the Executive Board (1987-1997), Vice President (19931994), and President (1995-1996). During his presidency he laid out the framework for the electoral process, which has given a broader segment of the ASC membership an opportunity to participate in the governance of the Society. In recognition of his great contributions to the field of cytopathology, Dr. Gupta received the highest honor of the ASC in 2001, the Papanicolaou Award. He was also the recipient of the 2011 Maurice Goldblatt Award of the International Academy of Cytology.

Deeply committed to the education of trainees and staff, Dr Gupta has left behind multiple generations of pathologists, cytopathologists, and cytotechnologists. In light of his dedication and long-standing service to the Department, the Hospital of the University of Pennsylvania Cytopathology sign-out room was named in honor of Prabodh K. Gupta in 2015. We all consider ourselves fortunate to have had the opportunity of coming under the influence of this truly great man. He had an innate ability to unite many with different views as team working together to serve our ultimate client "the patient."

Along with his many academic activities, Dr. Gupta was also an avid reader, collector of art and antique manuscripts, and an amazing cook. We all remember his famous barbecue, where he served his famous "tandoori chicken." We will all miss Dr. Gupta as the consummate teacher and a towering icon of cytopathology, as well as a friend and colleague.

Zubair W. Baloch 